\title{
An Assessment on Glare from Daylight through Various Designs of Shading Devices in Hot Humid Climate, Case Study in Kuala Lumpur, Malaysia
}

\author{
Zuraini Denan and Noor Hanita Abdul Majid
}

\begin{abstract}
Glare is one of the main problems that cause daylight to be visually undesirable in a hot humid country such as Malaysia. However, the design of modern buildings in Malaysia applies large glass windows and some partially covered with various design of shading devices, which are merely for aesthetic reason. Having sun shading devices have not solved the glare problems instead create either dark interiors or force for interior blinds and use of electrical lighting. Thus, this paper aims to investigate the glare performance under daylight through most common types of shading devices used in Kuala Lumpur, Malaysia. The four most common shading devices are: vertical, horizontal, egg-crate and geometrical pattern. The experiment covers the luminance, illuminance level and subjective responses of the occupants. The result indicates that under the vertical shading devices has spotted the highest glare values, in contrast subjective response indicate that the vertical shading devices provide most comfortable environment.
\end{abstract}

Index Terms-Daylight, glare, shading device, subjective responses, visual comfort.

\section{INTRODUCTION}

The study explores visual comfort looking through various shading device under the hot humid sky of Malaysia. Located near to the equator, Malaysia is one of the countries which are exposed to sunlight 12 hours per day and almost every day in a year. Taking advantage of the natural light so as to reduce electrical lighting consumption is not an easy solution. Direct light from the sun which is hot and glaring are the major problems. In an attempt of environmentally conscious design which leads to achievement of sustainable architecture, many new buildings were built trying to bringing as well as shading the daylight. Refer to Fig. 1. The idea is to filter the bright daylight from outside for visual comfort. Architects and building owners attempt to solve these problems by applying many types of shading devices, namely horizontal, vertical, egg-crate and geometrical pattern. However, these shading devices are seems not successful in avoiding glare and leading to the use of internal blinds. Consequently, office workers encounter insufficient light to perform their daily task. Thus, it is important to investigate on these common shading devices applied and to recommend the most

Manuscript received January 31, 2014; revised April 24, 2014. This work was supported in part by the International Islamic University Malaysia (IIUM) under the IIUM Endowment Grant EDW B11-206-064.

The authors are with the Department of Architecture, Kulliyyah of Architecture and Environmental Design, International Islamic University Malaysia (e-mail: zurainidenan@gmail.com,noorhanita@gmail.com). appropriate shading that can reduce the effect of glare, without sacrificing the advantage of the abundant daylight outside.

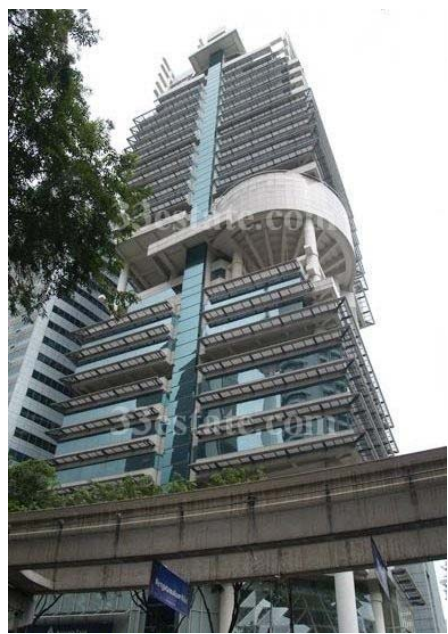

Fig. 1. Menara Prudential, Kuala Lumpur among: one of new high-rise, which attempt to implement sun-shading devices as green building approach

\section{AIMS AND OBJECTIVES}

The investigation aims to find out the shading devices which will be the most suitable in reducing glare. In order to achieve the aim several objectives were designed such as: First, to test most applicable sun shading devices in an experiment under the hot humid climate. Second, to record the illuminance and luminance values of the daylight filtered through the selected sun shading devices. Third, to analyse participants' preferences on the most suitable type of shading devices in reducing glare.

\section{LITERATURE REVIEW}

Application of shading devices is highly recommended for buildings in hot-humid region [1] Stewart (1977) and [2] Yeang (1987). Several studies have been conducted on shading devices regarding the effects of solar radiation [3] $\mathrm{Ku}$ Azhar and the amount of efficient illumination [4] S. Fadzil, S. and Sia, S.H (2003). Study by Azni [5] indicates that the light shelf with sloped overhang performs the best in reducing daylight factors (DF) and glare near windows. However, field measurement at office buildings with shading devices in Kuala Lumpur conducted by [6] Zuraini et al. (2003) indicated that sloped overhang produced glare at the windows. Refer to Table I. Among the sample measured, the vertical sun-shading has the lowest values but the glare was 
acceptable. The amount of illuminance and luminance does not seem to correlate. Thus, further investigation requires determining the most effective shading devices particularly based on the building occupants (subjective response).

TABLE I: SAMPLE FIELD MEASUREMENT AT KUALA LUMPUR OFFICE

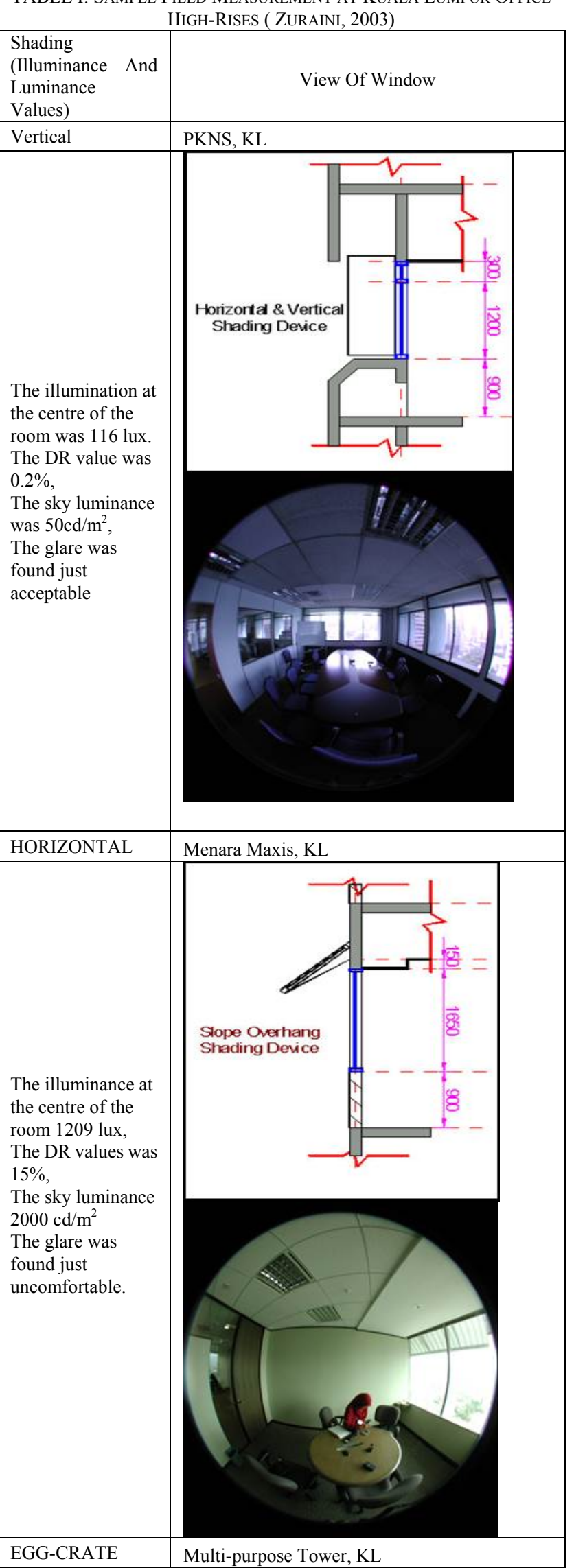

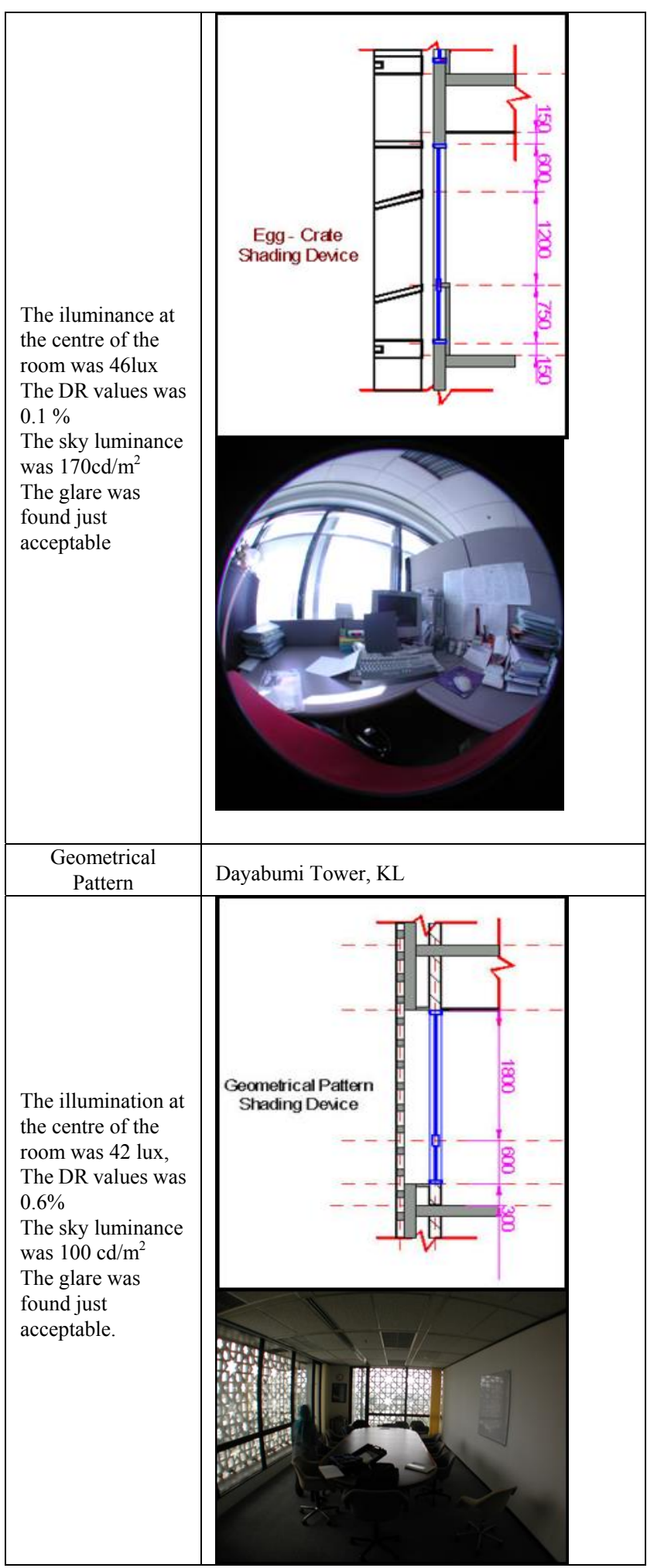

Visual comfort due to daylight that filtered by shading devices is the main achievement to this investigation. It is considered a complicated phenomenon. Several researches have defined the meaning of visual comfort. Visual comfort is a subjective phenomenon that involves perception of luminance in the field of view, excessive brightness, glare and eye adaptation. According to [7] Schiler and Japee (2001:27) visual comfort is "a state of vision when there is no existence of feeling psychological pain, irritation or distraction." The contrast levels and luminance differences across the space are two significant perimeters in considering the visual comfort within the space. 
Based on [8] Larson (1964) visibility and comfort are two different aspects of lighting that are seldom harmonized. He stated that psychological factors must also be considered, because seeing is dependent upon visual comfort for psychological health and well being. [9] Lam (1986) stated that feeling of comfort is influenced by what we see and perceive in the visual field of the overall luminous environment. According to [10] Szokolay (1980), sufficient amount of illuminance does not necessarily mean good lighting. However, the quality or suitability of lighting must also be considered. These criteria are luminance distribution, freedom from glare, directionality, the vector/scalar ratio, colour appearance and colour rendering and psychological and aesthetic effects. A good daylight design provides fully sufficient light for efficient visual performance and ensures a comfortable and pleasing environment appropriate to its purpose [11] (Hopkinson, Peterbridge, Longmore, 1966). In summary visual comfort, as most literature defines it, a base of a good lighting concept, enabling occupants to perform tasks quickly, accurately and safely, constituting a pleasant and satisfactory environment [12] (Pellegrino, 1999).

This level of visual comfort through daylighting has always been frustrated by the presence of excessive light or reflected light, which has caused many designers to avoid the use of daylight in design. The most obvious disadvantage of daylight is the glare that, if unchecked, reduces the level of visual comfort. The [13] CIBSE Lighting Handbook (1994) outlined the criteria of a visually comfortable daylit environment: it should have no existence of glare, an average Daylight Factor (DF) of not less than 2\%, clear visibility and be visually comfortable in terms of the visibility of a screen image and its contrast to the background. Other studies have limited the average DF to $5 \%$ in their description of a visually comfortable environment ([14] Zain, 2000; [15] Baker et al., 1993).

In relation to visual comfort study in Malaysia, [16] Zain (2000) has based her study on the CIBSE guidelines (2-5\% DF) in assessing alternative designs of shading devices. Her study, however, is conducted through laboratory experiment of scale model under artificial sky. Study of visual comfort under real office condition in Malaysia has not been explored.

Glare happen when there is an excessive amount of light coming directly from a source or reflected from a glossy surface. IESNA Daylighting Committee [17] describes glare happen when there is a "specular reflection of high surface illuminance in polished or glossy suface". Even though glare is generally avoided for reasons of visual discomfort, not all people are equally sensitive to glare. Based on IESNA, luminance of more than $200 \mathrm{~cd} / \mathrm{m}^{2}$ is considered severe. The recommended luminance based on type of work, office work ranges from $100-200 \mathrm{~cd} / \mathrm{m}^{2}$. Stone [18] reported that most people may not be aware of the existence of glare from interior lighting, whereas others may feel eye discomfort, headache and eye strain. At the extreme end of the scale, some researchers believe that glare can cause immediate discomfort and lead to potential fatigue and even danger [19] (Perry, 1995). Studies addressing glare are fairly common, however some questions relative to glare from daylighting remain unknown and unresolved [20] (Boubekri and Boyer,
1992).

\section{Method of Data Collection}

An experiment room with a window was set in the campus of the International Islamic University Malaysia. In the experiment, four common shading devices were selected (Table II) and prepared to be installed in the experiment. About fifty (50) students were arranged to be the subjects of experiment by asking them to sit at 6 different seats (A, B, C, $\mathrm{D}, \mathrm{E}$ and $\mathrm{F}$ ) that were arranged in the room. They were seat at the same position for each type of sun shading device tested in the experiment. The respondent was asked to identify any glare or bright source of light on the window, laptop monitor and book were asked to identified and rated from participants' seats. Glare rating assessment such as Intolerable, Uncomfortable, Acceptable and Perceptible were applied. Participants are also required to assess whether the condition is comfortable or uncomfortable to them.

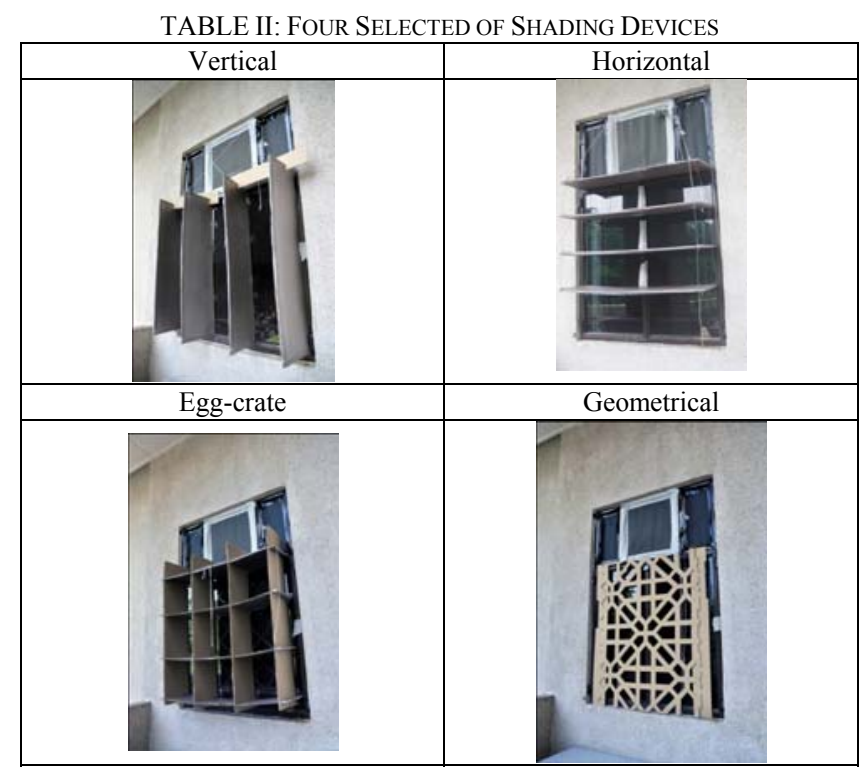

TABLE III: SUMMARY OF ILLUMINANCE AND LUMINANCE VALUES OF DAYLIGHT PERFORMANCE THROUGH Four SELECTED OF SHADING DEVICES

\begin{tabular}{|c|c|c|c|c|}
\hline & \multicolumn{4}{|c|}{ Types of Shading Devices } \\
\hline $\begin{array}{l}\text { Lighting } \\
\text { condition }\end{array}$ & $\begin{array}{c}\text { VERTICA } \\
\text { L }\end{array}$ & $\begin{array}{l}\text { HORIZO } \\
\text { NTAL }\end{array}$ & $\begin{array}{c}\text { EGG-CR } \\
\text { ATE }\end{array}$ & $\begin{array}{l}\text { GEOMET } \\
\text { RICAL }\end{array}$ \\
\hline $\begin{array}{l}\text { Average } \\
\text { illuminance } \\
\text { outside } \\
\text { (lux) }\end{array}$ & 113,000 & 271,500 & 335,500 & 829,000 \\
\hline $\begin{array}{l}\text { Luminance/ } \\
\text { glare on } \\
\text { window } \\
\left(\mathrm{cdm}^{2}\right)\end{array}$ & 4378 & 3233 & 2954 & 1213 \\
\hline $\begin{array}{c}\text { Illuminance } \\
\text { on Table } \\
\text { (lux) }\end{array}$ & $\begin{array}{l}12(\min )- \\
53(\max ) \\
33.7(\text { ave })\end{array}$ & $\begin{array}{l}4.4(\min )- \\
472(\max ) \\
77.1 \text { (ave) }\end{array}$ & $\begin{array}{l}11 \text { (min)- } \\
273 \text { (max) } \\
65.5 \text { (ave) }\end{array}$ & $\begin{array}{l}27(\min )- \\
261(\max ) \\
96.7 \text { (ave) }\end{array}$ \\
\hline $\begin{array}{c}\text { Luminance } \\
\text { on Table } \\
\left(\mathrm{cdm}^{2}\right)\end{array}$ & $\begin{array}{c}5.6(\min )- \\
51(\max ) \\
19(\text { ave })\end{array}$ & $\begin{array}{c}11(\min )- \\
524(\max ) \\
85.2(\text { ave })\end{array}$ & $\begin{array}{l}3.5(\min )- \\
71.3(\max ) \\
21.9 \text { (ave) }\end{array}$ & $\begin{array}{c}7.2 \text { (min)- } \\
160.9 \text { (max) } \\
39.3 \text { (ave) } \\
\end{array}$ \\
\hline $\begin{array}{l}\text { Luminance } \\
\text { on lap-top } \\
\text { monitor } \\
\left(\mathrm{cdm}^{2}\right)\end{array}$ & $\begin{array}{c}8.1(\min )- \\
169.9(\max ) \\
59.4 \text { (ave) }\end{array}$ & $\begin{array}{c}30.2(\mathrm{~min})- \\
155.8(\mathrm{max}) \\
89.2(\text { ave })\end{array}$ & $\begin{array}{l}64.8(\min )- \\
92.6(\max ) \\
77.1 \text { (ave) }\end{array}$ & $\begin{array}{c}47.3(\min )- \\
130.8(\max ) \\
81.1 \text { (ave) }\end{array}$ \\
\hline $\begin{array}{c}\text { Luminance } \\
\text { on } \\
\text { magazine } \\
\left(\mathrm{cdm}^{2}\right)\end{array}$ & $\begin{array}{c}2.0 \text { (min)- } \\
38.3 \text { (max) } \\
12.8 \text { (ave) }\end{array}$ & $\begin{array}{c}3.1(\mathrm{~min})- \\
144.6(\mathrm{max}) \\
37.3 \text { (ave) }\end{array}$ & $\begin{array}{c}2.9(\min )- \\
62(\max ) \\
19.3 \text { (ave) }\end{array}$ & $\begin{array}{c}3.9(\min )- \\
78(\max ) \\
29.3 \text { (ave) }\end{array}$ \\
\hline
\end{tabular}




\section{RESUlT AND ANALYSIS}

Experiment of four selected sun-shading devices: vertical, horizontal, egg-crate and geometrical pattern have successfully conducted in August 2012, which is one of the brightest sun in Malaysia. The illuminance and luminance values are summarized in Table III. Thus, the daylight captured during the experiment was one of the brightest values. The outside illuminances range from 113,000 to 829,000 lux. Glare on the window was significantly spotted at the top left area in all shading devices by the photos recorded. Refer to Table IV, glare on other spots are at random and happened not most of the time.

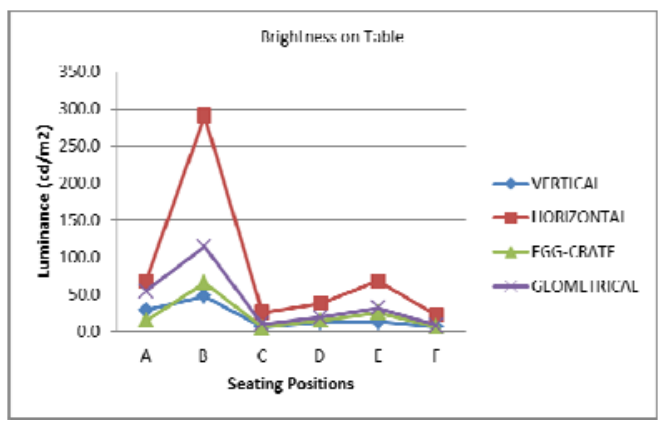

Fig. 2. Average brightness (luminance) on the table at different seating positions through various sun- shading devices.

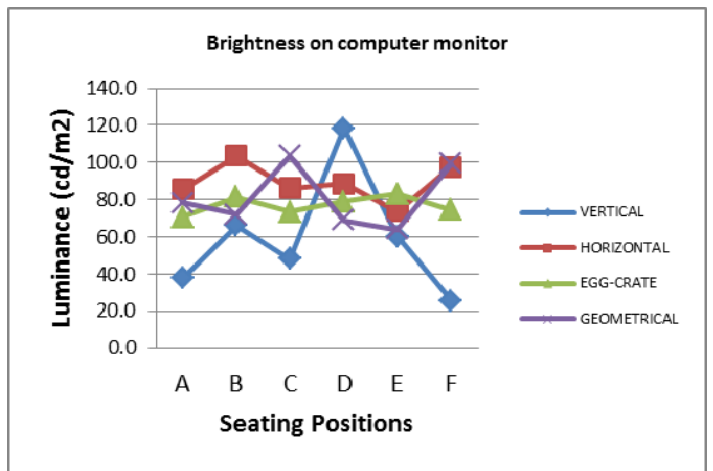

Fig. 3. Average brightness (luminance) on the lap-top monitor at different positions through various sun-shading devices.

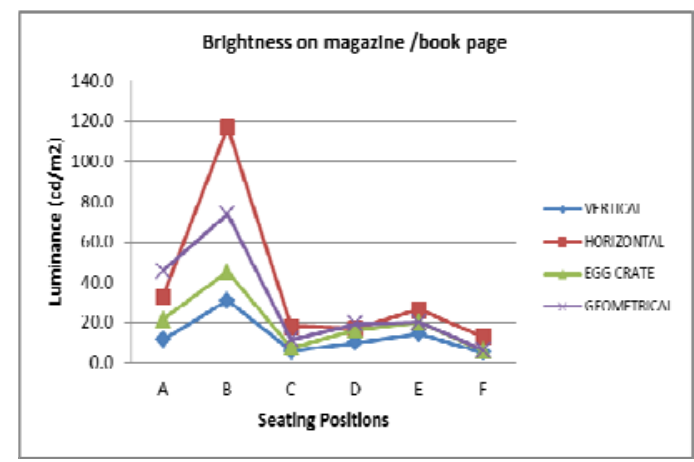

Fig. 4. Average brightness (luminance) on the magazine at different positions through various sun-shading devices.

The luminance values of the glare on that spot ranges from $3233-4378 \mathrm{~cd} / \mathrm{m}^{2}$. Glare is identified at all shading devices at one point. According to the Table III, the luminance values at vertical shading devices (the highest is $4378 \mathrm{~cd} / \mathrm{m}^{2}$ ) are considered very high, however the luminance values at the immediate surrounding (table, computer monitor and magazine) are mostly in low values. Refer to Fig. 2, Fig. 3, and Fig. 4. Subjective response indicated that most participants found the glare is acceptable and not distracting their work. Table IV showed the photographs for each of the daylight performance through each of the shading device. According to luminance values on the table (Fig. 2), on the computer monitor (Fig. 3) and on the magazine (Fig. 4), horizontal shading shows the highest values while the vertical shading indicates the lowest luminance values.

TABLE IV: The Glare Performance Through Selected Shading

\begin{tabular}{|l|l|}
\hline SHADING 1 & VERTICAL \\
\hline Luminance: \\
4378 cd/m ${ }^{2}$ \\
Illuminance: \\
113000LUX \\
Subjective \\
response \\
Suitability \\
Shading: 80\%
\end{tabular}

\section{CONCLUSION}

All shading devices have filtered the illuminance coming from outside extensively, however glare still can be seen through all shading devices. The identified glare are considered very high at all shading devices, however only few participants found the light at the window is glaring and the shadings are not suitable. The participants' eyes seem to adapt to the glare at the window. Refer to subjective perception of experiments' participants, the vertical shading devices are the most suitable to reduce glare. The egg-crate shading device is considered the least suitable.

All shading devices' performances in filtering the glare and light are rated acceptable. The result indicates that even though the values of the luminance are high and almost reaching $5000 \mathrm{cdm}^{2}$, the participants can still perform their task. This shows that all shading devices can be applied in hot humid climate such as Malaysia, vertical shading, which 
produces low luminance on the table and computer monitor, particularly is the most preferable by the occupants.

\section{ACKNOWLEDGMENT}

The deepest gratitude is forwarded to the International Islamic University Malaysia for the fund and support. Special appreciation to all participants of the experiment and research assistants, who have generously cooperated and assisted during the experiment.

\section{REFERENCES}

[1] J. R. Stewart, Solar Shading in Kuala Lumpur, Majalah Akitek, Pertubuhan Akitek Malaysia (PAM), pp. 45-47, Dec. 1977

[2] K. A. Yeang, "Review of Malaysian architecture (1957-1987)," Post-Merdeka Architecture Malaysia 1957-1987, Pertubuhan Akitek Malaysia (PAM), Kuala Lumpur, 1987.

[3] K. Azhar and K. Hassan, "The application of solar shading devices for buildings in hot humid climates with special reference to Malaysia," Ph.D. dissertation, School of Architecture, Cardiff University, Wales, UK, 1996.

[4] S. S. Fadzil and S. H. Sia, "Recommendations for horizontal shading depths for vertical building facades in the tropic region with particular reference to Penang, Malaysia," Architectural Science Review, vol. 46, no. 4, pp. 375-381, December 2003.

[5] A. A. Zain, "Daylighting and shading for thermal comfort in Malaysian building," Ph.D. dissertation, University of Hertfordshire., UK, 2000.

[6] Z. Denan, P. Jones, and D. Alexander, "The awareness of visual comfort through the application of passive low energy design in office building in Kuala Lumpur, Malaysia- a case study," presented at the Post-Graduate Conference, Lisbon, Portugal, April 2003

[7] S. M. J. Schiler, and S. Japee. Vital Signs: Interior Illuminance, Daylight Controls and Occupants Response, Vital Signs. [Online]. Available: $\quad \mathrm{http} / / / \mathrm{www}$. arch.ced.berkeley.edu/vitalsigns/, res/downloads/rp/daylight/day1_sml.pdf

[8] L. Larson, Lighting and its design, New York: Whitney Library of Design. 1964

[9] W. C. Lam, Sunlight as a Formgiver for Architectur, New York: Van Nostrand Reinhold. 1986

[10] S. V. Szokolay, Environmental Science Handbook for Architect and Builders, London: The Construction Press, 1980.

[11] H. Peterbridge, R. G. L. Hopkinson, P. Peterbridge, and J. Longmore, Daylighting, British Research Station, Watford: Heinemann, 1966.

[12] A. Pellegrino, "Assessment of artificial lighting parameters in a visual comfort perspective," Lighting, Research and Technology, vol. 31, no. 3, pp.107-115. 1999.

[13] CIBSE, Code of Interior Lighting, London: The Chartered Institution of Building Services Engineers, 1994.

[14] A. Zain, "Daylighting and shading for thermal comfort in Malaysian building," Ph.D. dissertation, University of Hertfordshire., UK, 2000.
[15] N. Baker, A. Fanciotti, and K. Steemers, Daylighting in Architecture: A European Reference Book, Comm. of the European Communities, James and James Science Publication, London, 1993.

[16] A. Zain, "Daylighting and shading for thermal comfort in Malaysian building," Ph.D. dissertation, University of Hertfordshire., UK, 2000.

[17] Recommended Practice of Daylighting, 5th ed. Illuminating Engineering Society of North America (IESNA), NY, 1978, p.7.

[18] P. T. Stone, "Flourescent lighting and health," Lighting Research and Technology, vol. 24, pp. 55-61, 1992.

[19] M. Perry, "Discomfort glare, light scatter, and scene structure," Ph.D. dissertation, Watford Building Research and Establishment, London, UK, 1995.

[20] M. Boubekri and L. L. Boyer, "Effect of window size and sunlight presence on glare," Lighting, Research and Technology, vol. 24, no. 2, pp. 69-74, 1992.

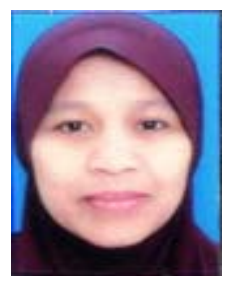

Zuraini Denan is an assistant professor at the Department of Architecture, Kulliyyah of Architecture and Environmental Design, International Islamic University of Malaysia, Kuala Lumpur. She received her bachelor of architecture degree from Texas Tech University, Texas, USA and master degree (MArch) from Universitoi Teknologi Malaysia, Skudai, Johor, Malaysia. Her $\mathrm{PhD}$ work is from the Cardiff University where she studied visual comfort (window and lighting under daylight of office buildings in hot humid country).

She involves in the review of the Malaysian Standard 2012 under the Department of Malaysian Standard (sirim 2011-2012). She is also a member of passive design group of the Japan society for the promotion of science-vice chancellors' council Of National Universities in Malaysia (jsps-vcc, 200-2009). She involves in advising on the daylighting issues at Kuala Lumpur Airport 2 under EAG consulting sdn bhd. Among her research interest are topics such as environment ( window, daylighting and visual comfort), architectural heritage and culture and human behavior.

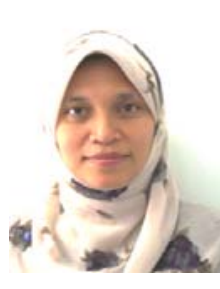

Noor Hanita Abdul Majid is an assistant professor at the Department of Architecture, Kulliyyah of Architecture and Environmental Design, International Islamic University of Malaysia, Kuala Lumpur. She completed her bachelor and master degrees in the field of architecture at University of Nebraska-Lincoln, USA. Her PhD work is from the University of Teknologi Malaysia where she studied outdoor thermal comfort of urban plazas. She is a receiver of research awards, i.e Veritas Research Award and Kajima Foundation, Japan and is actively involved in researches besides teaching.

Dr. Noor Hanita is currently involved in researches on passive and sustainable architecture, culture and behaviour, open spaces, housing and heritage buildings. She was involved in Affordable Housing Design at a national level and also some international consultancy works in Makkah and Oman. 